\title{
PENYULUHAN GEMAR KELOR DI DESA SUKARAJA PALAS LAMPUNG SELATAN
}

\author{
Anggraini ${ }^{1}$, Nita Evriana sari ${ }^{2}$ \\ ${ }^{1}$ Prodi DIV Kebidanan Universitas Malahayati \\ Email : anggraini@malahayati.ac.id \\ Nita.nuninosa@gmail.com
}

\begin{abstract}
ABSTRAK
Defisiensi zat besi dalam tubuh akan mengakibatkan anemia yang menurunkan jumlah maksimal oksigen yang dapat dibawa oleh darah, dan berakibat pula pada berkurangnya persediaan zat besi untuk memenuhi kebutuhan ibu, janin dan plasenta. Namun hal ini dapat diatasi dengan mengonsumsi Daun Kelor. Daun Kelor (Moringa oleifera Lam) merupakan salah satu tanaman lokal yang telah dikenal berabad-abad sebagai tanaman multiguna, padat nutrisi dan berkhasiat obat. Mengandung senyawa alami yang lebih banyak dan beragam dibanding jenis tanaman lainnya. Menurut hasil penelitian, daun kelor mengandung vitamin A, vitamin B, vitamin C, kalsium, kalium, besi dan protein dalam jumlah sangat tinggi yang mudah dicerna oleh tubuh manusia. Tingginya kandungan zat besi (Fe) pada daun kelor kering ataupun dalam bentuk tepung daun kelor yaitu setara dengan 25 kali lebih tinggi daripada bayam dapat dijadikan alternatif penanggulangan anemia pada ibu hamil secara alami. Maka dari itu kelompok memanfaatkan tanaman kelor sebagai program penyuluhan yang di beri nama "Gemar Tanam Kelor" yang dilaksanakan di Desa Sukaraja, Palas Lampung Selatan.
\end{abstract}

Kata Kunci : defisiensi zat besi, daun kelor

\section{ABSTRACT}

Deficiency of iron in the body will result in anemia which decreases the maximum amount of oxygen that can be carried by the blood, and results in reduced iron supplies to meet the needs of the mother, fetus and placenta. However, this can be overcome by consuming Moringa leaves. The leaves of Moringa (Moringa oleifera Lam) are a local plant that has been known for centuries as a multipurpose, nutrient dense and medicinal plant. Contains more and more various natural compounds than other types of plants. According to research results, Moringa leaves contain very high amounts of vitamin $A$, vitamin $B$, vitamin $C$, calcium, potassium, iron and protein which are easily digested by the human body. The high content of iron (Fe) in dried Moringa leaves or in the form of Moringa leaf powder, which is equivalent to 25 times higher than spinach, can be used as an alternative to treat anemia in pregnant women naturally. Therefore, the group made use of the Moringa plant as an extension program which was named "Loving to Plant Moringa" which was held in Sukaraja Village, Palas, South Lampung.

Keyword : iron deficiency, Moringa leaves 


\section{PENDAHULUAN}

Defisiensi zat besi dalam tubuh akan mengakibatkan anemia yang menurunkan jumlah maksimal oksigen yang dapat dibawa oleh darah, dan berakibat pula pada berkurangnya persediaan zat besi untuk memenuhi kebutuhan ibu, janin dan plasenta. Hal ini dapat menyebabkan berkurangnya transfer oksigen ke janin sehingga dapat berakibat pertumbuhan janin terhambat, peningkatan resiko persalinan pre term dan BBLR (Irianti dkk, 2014)

Permenkes No 97 tahun 2014 pasal 12 menyebutkan bahwa pelayanan kesehatan selama masa hamil bertujuan untuk memenuhi hak setiap ibu hamil memperoleh pelayanan kesehatan yang berkualitas sehingga mampu menjalani kehamilan dengan sehat, bersalin dengan selamat dan melahirkan bayi yang sehat dan berkualitas. Salah satu upaya pemerintah untuk mengatasi anemia defisiensi besi pada ibu hamil adalah dengan pemberian tablet tambah darah (Fe). Departemen Kesehatan telah melaksanakan progam penanggulangan anemia defisiensi besi pada ibu hamil dengan membagikan tablet besi berturut-turut 90 hari selama masa kehamilan (Kemenkes,2014).

Menurut Budiarni (2012) salah satu faktor yang menyebabkan masih meningkatnya angka anemia defisiensi besi pada ibu hamil disaat cakupan distribusi tablet besi sudah melewati target adalah rendahnya kepatuhan ibu hamil dalam mengkonsumsi tablet besi. Sebanyak $51.8 \%$ ibu hamil dinyatakan tidak patuh dalam mengkonsumsi tablet besi. Selain itu ada beberapa alasan yang dikemukakan ibu hamil terkait kelemahan tablet besi sehingga ibu hamil tidak menghabiskan tablet besi yang sudah diterimanya, mulai dari bau dan rasa tablet besi yang sulit diterima karena menyebabkan mual setelah minum tablet besi hingga BAB berwarna hitam.

Daun Kelor (Moringa oleifera Lam) merupakan salah satu tanaman lokal yang telah dikenal berabad-abad sebagai tanaman multiguna, padat nutrisi dan berkhasiat obat. Mengandung senyawa alami yang lebih banyak dan beragam dibanding jenis tanaman lainnya. Menurut hasil penelitian, daun kelor mengandung vitamin $A$, vitamin $B$, vitamin $C$, kalsium, kalium, besi dan protein dalam jumlah sangat tinggi yang mudah dicerna oleh tubuh manusia. Tingginya kandungan zat besi $(\mathrm{Fe})$ pada daun kelor kering ataupun dalam bentuk tepung daun kelor yaitu setara dengan 25 kali lebih tinggi daripada bayam dapat dijadikan alternatif penanggulangan anemia pada ibu hamil secara alami. Kandungan senyawa kelor telah diteliti dan dilaporkan oleh Ibok Odura W, O Ellis, at all (2008) menyebutkan bahwa daun kelor mengandung besi $28,29 \mathrm{mg}$ dalam 100 gram.

\section{MASALAH}

Di Desa Sukaraja sendiri setelah dilakukan pendataan kesehatan penduduk selama 2 minggu didapati kasus ibu hamil dengan anemia ringan. Hal ini membuat kami tertarik untuk melakukan penyuluhan sekaligus program gemar menanam tumbuhan kelor. Penyuluhan ini ditujukan oleh para kader kesehatan. Promosi kesehatan ini dilakukan agar mereka dapat menolong ibu hamil dengan anemia, serta mengembangkan kegiatan yang bersumber 
pada masyarakat, sesuai dengan kondisi sosial budaya setempat dan didukung oleh kebijakan secara internal maupun lingkungannya yang berwawasan kesehatan.

Program ini dibentuk dengan melakukan pendataan terlebih dahulu pada seluruh sampel masyarakat Desa Sukaraja selama 2 minggu. Setelah itu terbentuklah "Gemar Tanam Kelor" sebagai acuan nya yaitu ibu hamil dengan anemia. Program ini dilaksanakan dengan melakukan penyuluhan terlebih dahulu dengan para kader Desa Sukaraja. Metode penyuluhan yang di pakai adalah dengan ceramah, Tanya jawab, diikuti oleh demonstrasi menanam tumbuhan kelor secara langsung.

\section{METODE}

Penyuluhan Program gemar tanam kelor dilakukan pada tanggal 25 maret 2021 di Balai Desa Sukaraja. Dihadiri oleh 10 orang kader desa Sukaraja. Dijelaskan bahwa, setelah dilakukan pendataan kesehatan penduduk selam 2 minggu di dapati ibu hamil anemia.

a. Tujuan Persiapan Tahap persiapan dari kegiatan adalah pre planning, persiapan penyajian dengan alat demo melalui video, LCD

b. Tahap Pelaksanaan tanggal 25 Maret $2021 \mathrm{Jam}$ 13.00 Wib.

c. Acara ini dengan pemberitahuan kepada Kepala desa desa Sukaraja dan Bidan lapangan untuk meminta izin mengadakan penyuluhan dan demo terhadap kader desa sukaraja.

\section{HASIL DAN PEMBAHASAN}

Program Gemar Tanam Kelor yang diikuti olah 10 kader di Desa Sukaraja berjalan dengan baik. Kader dapat memahami manfaat tanaman kelor untuk kesehatan khususnya pada ibu hamil dengan defisiensi zat besi. Selain itu, kelompok mampu mengajarkan kader cara menanam tumbuhan kelor yang diharapkan para kader dapat membagikan ilmunya pada masyarakat sekitar ataupun pada kader di desa lainnya.

Program gemar tanam kelor ini bertujuan agar dapat menanggulangi masalah defisiensi zat besi yang terjadi pada ibu hamil di desa Sukaraja seklaigus, mengajak masyarakat desa dusun Sukaraja menggalakkan gerakan menanam kelor sehingga menjadikan dusun tersebut sebagai Kampung Kelor, dimana masyarakat mampu secara mandiri membudidayakan, memanfaatkan tanaman kelor untuk kesehatan, dan penambah nutrisi, khususnya bagi ibu hamil dengan anemia bahkan menyebar luaskan informasi tentang pemanfaatan kelor sebagai tanaman herbal pada masyarakat dusun lainnya.

Sosialisasi tentang berbagai nutrisi yang ada pada kelor dan membandingkan manfaatnya bagi ibu hamil penderita anemia menunjukkan bahwa kelor meskipun hanya sayuran tetapi punya kandungan nutrisi yang sangat baik manfaatnya. Selain itu juga mengadakan gerakan menanam kelor yang diikuti oleh ibu-ibu kader dusun Sukaraja . Harapannya masyarakat lebih bersemangat mengkonsumsi kelor, karena diolah menjadi aneka makanan tidak harus dalam bentuk jamu atau kapsul. Makanan berbahan baku kelor yang dibuat ibu -ibu warga Dusun Sukaraja Selain itu juga sosialisasi tentang 
manfaat kelor sebagai herbal dalam kegiatan tersebut sekaligus mendetilkan beberapa penyakit yang bisa sembuh dengan mengkonsumsi tanaman kelor.

Selain itu terbentuk kader kelor dusun Sukaraja juga diharapkan menularkan program "gemar tanam kelor" ini ke dusun lain sekitar Sukaraja atau daerah lain, dimana kader kelor dusun Sukaraja bertindak sebagai narasumber.

\section{KESIMPULAN}

Kesimpulan dari kegiatan penyuluhan Program Gemar Tanam Kelor yang diikuti olah 10 kader di Desa Sukaraja berjalan dengan baik. Kader dapat memahami manfaat tanaman kelor untuk kesehatan khususnya pada ibu hamil dengan defisiensi zat besi. Selain itu, kelompok mampu mengajarkan kader cara menanam tumbuhan kelor yang diharapkan para kader dapat membagikan ilmunya pada masyarakat sekitar ataupun pada kader di desa lainnya. Dan terdapat Adanya peningkatan $80 \%$ pengetahuan Kader tentang manfaat Daun Kelor.

\section{DAFTAR PUSTAKA}

Amzu, 2014. Kampung Konservasi Kelor: Upaya Mendukung Gerakan Nasional Sadar Gizi Dan Mengatasi Malnutrisi Di Indonesia. Risalah Kebijakan Pertanian dan Lingkungan. Vol. 1 No. 2: 86

Bahriyah, Izzatul, Hayati, Ari, Zayadi, Hasan. 2015. Studi Etnobotani Tanaman Kelor (Moringa oleifera) di Desa Somber Kecamatan Tambelangan Kabupaten Sampang Madura. e- Jurnal Ilmiah BIOSAINTROPIS (BIOSCIENCETROPIC) Volume :1 (1), 2015, 61 - 67

Dahlan Sopiyudin . M. 2009 : Statistik untuk kedokteran dan Kesehatan Edisi 4 . Penerbit Salemba Medika Jakarta. Depkes RI, 2003.

Program Penanggulangan Anemia Pada Wanita Usia Subur (WUS). Direktorat Gizi Masyarakat, Direktorat Bina Kesehatan Masyarakat. Http : II Anemia.Com. Tesis Simajuntak, 2008. Hubungan Anemia Pada Ibu Hamil Dengan Berat Badan Bayi Baru Lahir Di Rumah Sakit Ranturapat.

Susilawati, S., Sari, D. K., \& Novita, N. (2021). SOSIALISASI INOVASI KEGIATAN “KASI HATI"(KADER SIAGA HAMIL RESTI) DI KELURAHAN PALAPA DI KOTA BANDAR LAMPUNG TAHUN 2021. JURNAL PERAK MALAHAYATI, 3(1), 37-45.

Agusmayanti, R., Farich, A., \& Anggraini, A. (2020). PEMBERIAN VITAMIN C DAPAT MENINGKATKAN KADAR HEMOGLOBIN PADA IBU HAMIL ANEMIA. JKM (Jurnal Kebidanan Malahayati), 6(3), 342-348. 